\title{
THE QUALITY MANAGEMENT SYSTEM IN COMPANY - THE MARKET SITUATION AND CUSTOMER PERCEPTION
}

\author{
Katarzyna Brendzel-Skowera \\ Czestochowa University of Technology \\ Faculty of Management
}

\begin{abstract}
The quality of product / service is a key factor influencing on relationships with customers and business partners. The tools that are designed to guarantee an enterprise to achieve and maintain a certain level of quality of the offered products, are the Quality Management Systems. This article is devoted to assessing the impact of quality management systems on company's competitiveness. The aim of the study was analysed by a case study of the foundry company. The key effects of QMS influence on the competitiveness of the researched company are the minimization of the use of raw materials, natural resources, the number of deficiencies and complaints. The average value of these indicators keeps the company below the established limit.
\end{abstract}

Keywords: Competitiveness, management, the Quality Management Systems

DOI: $10.17512 /$ znpcz.2017.4.1.03

\section{Introduction}

Quality management systems in the form of ISO 9000 standards were first published in 1987. Since then, successive versions of the quality management system has been implemented by organizations with different business characteristics. The impact of the management system can be seen in many ways the functioning of the company. Starting from better work organization, greater supervision of the product and ending with the increasing attractiveness to potential new customers. The impact of the quality management system for improvement of the organization can be traced also through the action of system tools that the end result is to increase the efficiency of the company in its area of operations.

The subject of the article is to evaluate the impact of quality management systems for company's competitiveness. The purpose of the article was based on the case study of the company that manufactures and sells iron castings. This firm manufactures castings in grey cast iron for the construction, machine-building and automotive industries. The annual output of the foundry amounts to approximately 9000 tonnes of castings. The factory's production programme covers nearly 800 items. About $80 \%$ of the output is exported to foreign markets ${ }^{1}$. This company operates the System of Quality and Environmental Management according to PN-EN ISO 9001:2009 and PN-EN ISO 14001:2005. These systems affect the

\footnotetext{
${ }^{1}$ According to the company data.
} 
company's competitiveness. This is confirmed by the analysis of the following indicators: of flawed production, electric energy and gas usage, waste produced during production and raw material consumption.

\section{The Quality Management Systems (QMS)}

The result of quality management is improvement of the entire organization and the creation of high-quality product in accordance with the expectations of the environment. Through quality management you can determine the activity of management that focuses on quality tasks and its implementation for the benefit of the entire organization. The functions of quality management include planning, organization of quality systems, motivation and quality control (Bieńkowska, Zabłocka-Kluczka 2005, p. 77).

High competition, aimed at obtaining customer and maintaining position in the market affects the functioning of the organization, this creates the need to make decisions to improve quality under a specific quality management system (Mrozik 2013, p. 83). Quality management system can be defined as a set of mutually correlated and interacting with each other elements that allows clarification of objectives and implementation of policies needed to realize these goals, but also to formation of encouraging support of organization's management and its supervision in terms of quality (PN-EN ISO 9000:2006, p. 27-31).

The quality management system determines the rules of conduct in order to develop the organization by seeking to produce goods and services of the highest possible quality, in order to meet customer needs (Klimecka-Tatar, Kowalik 2017). The activities carried out in accordance with the principles of the quality management system also allows you to increase the efficiency and effectiveness of the company (Olkiewicz 2012, p. 205).

Quality management systems are part of standards developed by the International Organization for Standardization. These standards include also other technical documents published by the ISO/TC 176 technical committee, as well as all kinds of reports, specifications and brochures (Ejdys, Kobylińska, Lulewicz-Sas 2012 , p. 34). International standards and ISO documents, valid until 2015, and their polish equivalents, relating to the quality management process are summarized in the Table 1.

On the basis of ISO 9000 standards, a number of standardizing different management systems norms were created. Legal requirements, but above all customer expectations are forcing on companies the need to implement some requirements of the standards system (eg. ISO 9001, ISO 14001, ISO 27001, OHSAS 18001), as well as industry standards (eg. TS 16949, ISO 13485, HACCP). It is a typical effect, especially for areas where there are significant risks. 
Table 1. Summary of international ISO 9000 series standards and documents and their Polish equivalents

\begin{tabular}{|c|c|c|}
\hline $\begin{array}{l}\text { Symbol of norm } \\
\text { (Polish symbol) }\end{array}$ & Year & The title \\
\hline $\begin{array}{l}\text { ISO } 9000 \\
\text { (PN-EN ISO } \\
9000: 2006)\end{array}$ & 2005 & $\begin{array}{l}\text { Quality management systems - Fundamentals and } \\
\text { vocabulary }\end{array}$ \\
\hline $\begin{array}{l}\text { ISO 9001 } \\
\text { (PN-EN ISO } \\
9001: 2009)\end{array}$ & 2008 & Quality management systems - Requirements \\
\hline $\begin{array}{l}\text { ISO } 9004 \\
(\mathrm{PN}-\mathrm{EN} \text { ISO } \\
9004: 2010) \\
\end{array}$ & 2009 & $\begin{array}{l}\text { Managing for the sustained success of an organization. } \\
\text { A quality management approach }\end{array}$ \\
\hline $\begin{array}{c}\text { ISO } 10001 \\
(-)\end{array}$ & 2007 & $\begin{array}{l}\text { Quality management - Customer satisfaction - Guidelines } \\
\text { for code of conduct for organizations }\end{array}$ \\
\hline $\begin{array}{c}\text { ISO } 10002 \\
(-)\end{array}$ & 2004 & $\begin{array}{l}\text { Quality management - Customer satisfaction - Guidelines } \\
\text { for complaints handling in organizations }\end{array}$ \\
\hline $\begin{array}{c}\text { ISO } 10003 \\
(-)\end{array}$ & 2007 & $\begin{array}{l}\text { Quality management - Customer satisfaction - Guidelines } \\
\text { for dispute resolution external to organization }\end{array}$ \\
\hline $\begin{array}{c}\text { ISO 10005 } \\
\text { (PN-ISO 10005:2007) } \\
\end{array}$ & 2005 & Quality management - Guidelines for quality plans \\
\hline $\begin{array}{c}\text { ISO } 10006 \\
(\mathrm{PN}-\mathrm{ISO} 10006: 2002)\end{array}$ & 2003 & $\begin{array}{l}\text { Quality management systems - Guidelines for quality } \\
\text { management in projects }\end{array}$ \\
\hline $\begin{array}{c}\text { ISO } 10007 \\
(\mathrm{PN}-\mathrm{ISO} 10007: 2005) \\
\end{array}$ & 2003 & $\begin{array}{c}\text { Quality management systems - Guidelines for configuration } \\
\text { management }\end{array}$ \\
\hline $\begin{array}{l}\text { ISO } 10012 \\
\text { (PN-EN ISO } \\
10012: 2004)\end{array}$ & 2003 & $\begin{array}{l}\text { Measurement management systems - Requirements for } \\
\text { measurement processes and measuring equipment }\end{array}$ \\
\hline $\begin{array}{c}\text { ISO/TR } 10013 \\
(-)\end{array}$ & 2001 & $\begin{array}{l}\text { Guidelines for quality management system documentation } \\
\text { (available in English only) }\end{array}$ \\
\hline $\begin{array}{c}\text { ISO } 10014 \\
(\mathrm{PN}-\mathrm{ISO} 10014: 2008) \\
\end{array}$ & 2006 & $\begin{array}{l}\text { Quality management - Guidelines for realizing financial } \\
\text { and economic benefits }\end{array}$ \\
\hline $\begin{array}{c}\text { ISO 10015 } \\
\text { (PN-ISO 10015:2004) } \\
\end{array}$ & 1999 & Quality management - Guidelines for training \\
\hline $\begin{array}{c}\text { ISO/TR 10017 } \\
\text { (PKN-ISO } \\
\text { TR10017:2007) }\end{array}$ & 2003 & Guidance on statistical techniques for ISO 9001:2000 \\
\hline $\begin{array}{c}\text { ISO 10019 } \\
\text { (PN-ISO 10019:2006) } \\
\end{array}$ & 2005 & $\begin{array}{l}\text { Guidelines for the selection of quality management system } \\
\text { consultants and use of their services }\end{array}$ \\
\hline $\begin{array}{c}\text { ISO/TS } 16949 \\
(-)\end{array}$ & 2002 & $\begin{array}{c}\text { Quality management systems - Particular requirements for } \\
\text { the application of ISO 9001:2000 for automotive production } \\
\text { and relevant service part organizations }\end{array}$ \\
\hline $\begin{array}{c}\text { ISO 19011 } \\
\text { (EN ISO 19011: 2011) } \\
\end{array}$ & 2011 & Guidelines for audyting management systems \\
\hline
\end{tabular}

Source: (Ejdys, Kobylińska, Lulewicz-Sas 2012, p. 35-36)

In addition to the quality management system in parallel there are many other systems, but the most important should be two other standardized management systems (Ejdys, Kobylińska, Lulewicz-Sas 2012, p. 10): 
- PN-EN ISO 14001:2005 Environmental management systems. Requirements with guidance for use;

- PN-N 18001:2004 Occupational health and safety management systems.

Requirements.

A very important issue is the integration of management systems through the improvement and optimization of processes within the organization and to enable cooperation at the level of individual management systems, taking also into account external processes implemented by suppliers and subcontractors (Matuszak-Flejszman 2010, p. 199). Integration of management systems should be carried out on the basis of a strategic decision of the management, and the decision should be preceded by a clarification of objectives, expectations, results and planned costs of the project.

Enterprises prefer the method of integration of quality management and environmental management through the use of operating elements of the quality management system to implementation of an environmental management system (Olejniczak 2015, p. 55). The elements favorable to such integration include mainly common system procedures, unified documentation and records and supervision of the system which uses an internal audit and control processes. The basic factors that help in the implementation of the environmental management system, when the quality management system is already in place include (Ejdys, Kobylińska, Lulewicz-Sas 2010, p. 12-13):

- similar philosophy and the requirements of both standards, which favors the interpretation of ISO 14001;

- the ability to connect similar procedures on both standards, which greatly simplifies documentation;

- a chance to capitalize on the experience and practice of coordinators supervising existing management systems;

- intertwining of environmental and quality control issues in controlling processes of the enterprise.

Common features of three systems that allows continuous expanding and improving unit management system may include (Mroczko 2012, p. 102-105):

- commitment of top management,

- system documentation,

- training system and communication,

- system of internal audits and management reviews.

The end result of systems integration should be specified common policy of quality, environment and safety at work, which is a basis for defining the objectives and plans and operational programs. Use in the course of designing, organizing and implementing of an integrated management system quality management principles: the process and system approach, identification of the processes as a business and to highlight the expectations of all interested parties, will result in minimizing the practical problems related to the integration of the system, provided that the unique requirements of each individual standard will be taken into account (Kleniewski 2004, p. 9). 
International ISO standards provide a credible publications of: standardization organizations, international non-profit organizations, trade unions and associations. An approach based on standardization assumes that the standards (Ejdys, Kobylińska, Lulewicz-Sas 2010, p. 9-10):

- use the terminology accepted by all organizations, regardless of the nature and type of activity;

- introduce a requirement for organizations to implement and develop formal systems that control the areas affected;

- commit to implement a system of internal and external controls, audits;

- oblige to confirm compliance with the requirements of the standard by independent, external, accredited certification units.

In Poland, the standardization unit is the Polish Committee for Standardization (PKN - Polski Komitet Normalizacyjny), whose tasks include, among others (Ustawa z dnia 12 września 2002 r. ..., art 11):

- determination of the status and development trends of standardization;

- organization and supervision of activities involving the development and dissemination of Polish Standards and other standardization documents;

- Polish representation in international and regional standardization organizations;

- organization and conduct of training activities, publishing, promotion and information on standardization;

- to give opinions on drafts of legal acts relating to standardization.

The latest achievement of the norm standardization process in quality management system, inducing the process of integration of co-existing standards regulating the management process is to complete on the second half of year 2015 the process of amendment of the two most commonly used standards: ISO 9001 and ISO 14001. At that time they also published the new ISO 9000 norm "Quality management systems - Fundamentals and vocabulary", which defines basis for management systems and terminology introduced for standards of quality management. Revision of ISO 9001 was carried out based on the user experience, the evolution of the practices, techniques of management systems, and taking into account changes in the environment of the organization. The fundamental purposes of that amendment include the need to adapt to the variability of the composite organization's environment, ensuring stability and prospective unification of the standards of other management systems, taking into account the needs of all parties, which is dedicated to the norm. The main changes introduced by the ISO 9001:2015 include (Berdowski 2016, p. 26):

- Implementation of the structure specified in Annex SL, Part 1 of the ISO / IEC;

- Redrafted for ease of use by service organizations;

- Taking into account the context of the organization and interested parties relevant to the environmental management system and their requirements (needs and expectations);

- Determination of the scope of the management system;

- The adoption of risk-based approach in the planning, implementation and operation of the system; 
- Ensuring the integration of the management system requirements with the business process of organization;

- Increased involvement of top management in effective quality management throughout the company;

- A flexible approach to documentation; the organization will have greater freedom in deciding what information is documented for the appropriate and useful;

- Enhanced focus on achieving the desired results in order to increase customer satisfaction;

- The need to identify and maintain the knowledge needed for the operation of processes and obtaining conformity of products and services.

Normalization is the basis for activities of enterprises primarily due to the fact that the granting of a certificate which confirms the use by the organization required standards serves both the development of the company as well as customer acquisition and strengthening market position. Today's actions are aimed at strengthening the international standards. In the context of increasing globalization, it becomes obvious that maintaining the appropriate position relative to the competition requires companies to preserve all necessary standards contained in the norms. In order to be competitive on international markets Polish companies must adapt to these systems recognized and respected in other countries (Zawiślak 2013, p. 49).

\section{The quality management in the company - case study}

The subject of activity of the researched company is the production and sale of cast iron. In the long history (the company was founded in 1894) of this firm can be see a numerous innovations of a different nature. Some of them are minor technological and organizational improvements resulting from the initiative of the workers themselves, and they do not require a change in strategy of the firm. Moreover among them there are both the innovation of process and product, inspiration of which was taken from the desire to improve the quality of products and the production process.

To meet current and future demands of the market as domestic and foreign, in 1994 actions have been taken to develop and implement a quality assurance system in accordance with ISO 9000. The documentation of the quality assurance system has been assessed by the auditors from Polish Centre for Testing and Certification, and then in December 1996 took place the certification audit which resulted in receiving a PCBC certificate confirming the compliance of the quality assurance system model according to the ISO 9002 standard. The implemented quality system gave the foundry guarantee of an adequate level of quality of manufactured castings, however, it is not the only factor in the development of the company and in constant efforts to meet customer expectations.

Work on the implementation of the Environmental Management System based on the international standard ISO EN 14001 began in 1998. Management found to the experiences of Quality System Standards of ISO 9002 implemented in 1996 to 
be helpful in this case. As a result on 15 VIII 1999 r. company implemented the Integrated Quality and Environmental Management System according to ISO 9002 and ISO 14001. On October 28, 1999. certification audit was carried out, under which the Plant was awarded the relevant certificate. It should be noted that all the work on the implementation of the Environmental Management System have been carried out by employees. It should be underlined that as conducted modernization activities have also greatly improved working conditions. It eliminated the hard work of people - typical for foundries, involving the transport of metal, filling and creation of forms. Man has been replaced by the special machinery. Excessive dust and noise in the workplace were eliminated. At present, the plant does not exceed the permissible standards for workplaces in the range of typical for foundry harmful factors, i.e. the noise and dust. The plant has been removed as probably the only foundry in Poland, from the list of companies with particularly difficult conditions.

Currently, the company operates the System of Quality and Environmental Management according to PN-EN ISO 9001:2009 and PN-EN ISO 14001:2005. On the basis of the decision of the Marshal of the Silesian Provence this company has received on 26.07.2007 one of the last integrated permits for installations for casting ferrous metals. This license is very important for the functioning of management systems because it defines directly levels of emissions of gases and dust which are allowed for this type of business activity. Based on these limits the company define the goals and objectives towards to which will be aimed and the methods of improvement for the functioning of the organization in order to obtain better results from year to year. The researched company in concern for the environment in its immediate neighborhood sets out clear goals and objectives due to execution of the formulated in accordance with ISO14001:2005 procedures that are updated every year. Goals and objectives are established in accordance to both the ISO 14001:2005 and ISO 9001:2009. The difference is that the goals and objectives relative to the standard ISO 9001:2009 are qualitative as opposed to the ISO 14001:2005 which describes the rules and procedures to follow in the case of environmental protection activity during production.

\section{The impact of aspects of QMS on the competitiveness of the researched company}

To determine which of the various aspects of these standards has a direct impact on the results achieved by the company in the case of competition in the international market must be to assess carefully the various points of the standards and their interpretations by the company. Each company by implementing quality management systems and environmental management assesses factors or levels of performance which is going to pursue. The selection needs to be made based on the characteristics of activity. Factors related to quality management could be shares of the defective production, levels of customer complaints or for example levels of consumption of utilities such as electricity, gas and water during production. Determinant in terms of environmental management standards may be the analysis of the emission of pollutants such as dusts and gaseous substances as well as 
sewage contamination. A very frequent factor for foundries are also the shares of individual alloying additives or raw materials needed to obtain proper operation of the furnace.

For the proper functioning of the systems through continuous monitoring and audits the management designated employee that is responsible for it. Audits in the case of the researched firm are based on checking the functioning of the organization in terms of working according to procedures and continuing actions for pursue of the set goals. Examining whether the company complies to established according to the ISO document Objectives and Organization quality goals values and that it tends to accomplish the anualy set targets. Other issues that are checked during audits is updates of legislation (laws, regulations, notices) that may relate to environmental standards. Another example of monitored aspects during the audit are the company's agreement with suppliers of utilities (electricity, gas, water). The most important, however, is to check the compliance with the work procedures and workstation instructions in this company and checking the work environment in the production division.

All of the factors above, as well as proceedings in the course of checking the functioning of ISO systems in the organization have a direct impact on the obtained value of the company's competitiveness on the market. Striving to achieve the values set in the annually prepared documents relating to the objectives and challenges faced by the Company becomes a determinant of the company's development. Any factor and indicator which is fulfilled in relation to previous findings becomes another step to improve the efficiency of the organization and therefore its position in the market as well as the ability to compete with other companies in the industry.

The first of these factors in this study is the defective production factor. Each production is burdened with risk of parts with defects. The tendency to solve the problem of defects in the form of larger or total elimination is the pursuit of every organization. A progressive lowering of the level of defective products during production increases its profitability and therefore competitiveness of companies in the broader sense. Example of monitoring the rate of products with defects in the production is in Figure 1. 


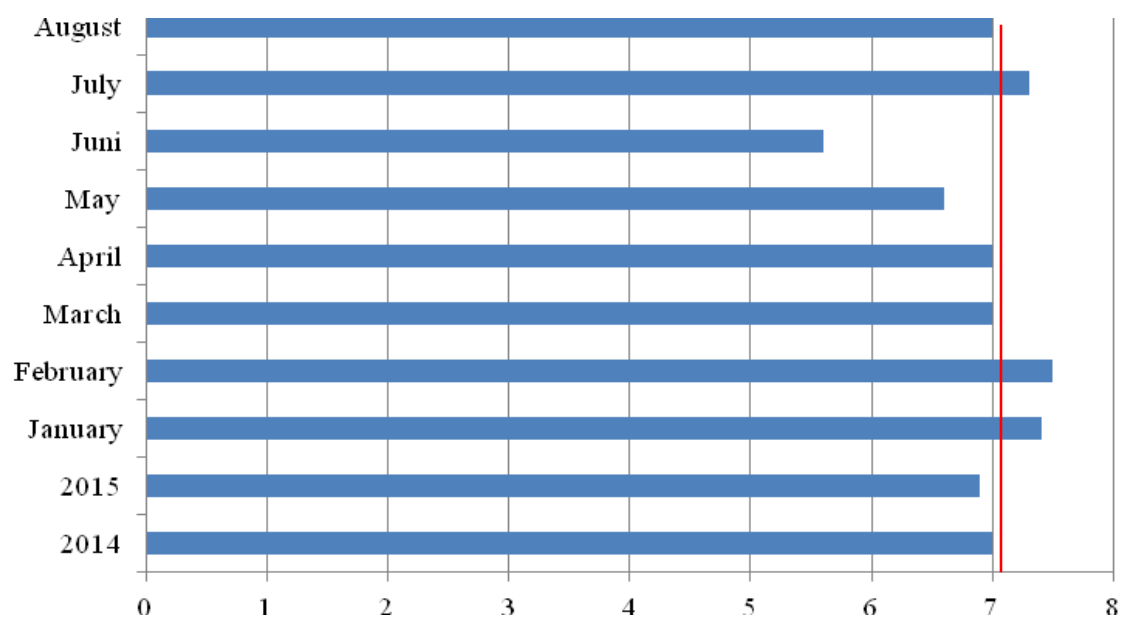

Foundation for 2016 max. $7.5 \%$

Figure 1. Indicators of flawed production in 2014-2016 [\%]

Source: Developed based on the company materials

In the figure we can see defects involved in the production and accepted values. The company set the targets for 2016 that production of defected castings must not exceed $7.5 \%$ of the total production. In the second half of 2016, value was achieved $6.9 \%$.

Factors which translates into competitiveness as well as to reduce the harmful effects on the environment are the consumption of utilities such as electricity, gas and water. At this company main electricity consumption is due to the supply of the production line, automatic machinery and devices in both production and monitoring of several production parameters. For devices that have an impact on the increase in electric consumption we can also include factory information network and its internal database. Indicators of use of electricity in the company are shown in Figure 2. Electricity consumption for eight months is $537.2 \mathrm{kWh} / \mathrm{Mg}$ which is within the designated for this year limit set at $570 \mathrm{kWh} / \mathrm{Mg}$.

Figure 3 shows the rates of gas consumption. The maximum value established for the year 2016 amounts to $39.0 \mathrm{~m}^{3}$ while achieved value of gas consumption in 8 months is $37.84 \mathrm{~m}^{3}$ of gas per tonne of produced cast iron. Impact on gas consumption in the foundry have factors such as gas-fired furnace heating installations and gutters supplying molten metal into molds. Heating of the furnace is carried out both in the preparatory process for the production as well and during the production. Gas is also used to heat the hot water for social needs in factory's boiler room. In 2016 the company reached a value below the maximum set what is shown in the figure below. 


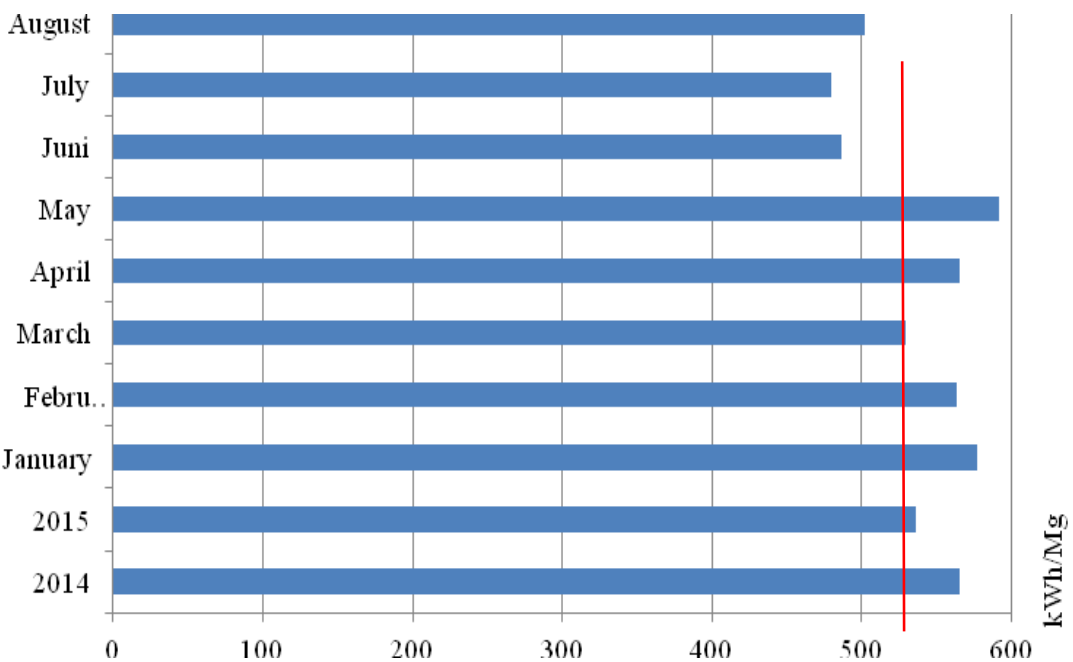

- Foundation for 2016 max. $570 \mathrm{kWh} / \mathrm{Mg}$

Figure 2. Indicators of electric energy usage in 2014-2016

Source: Developed based on the company materials

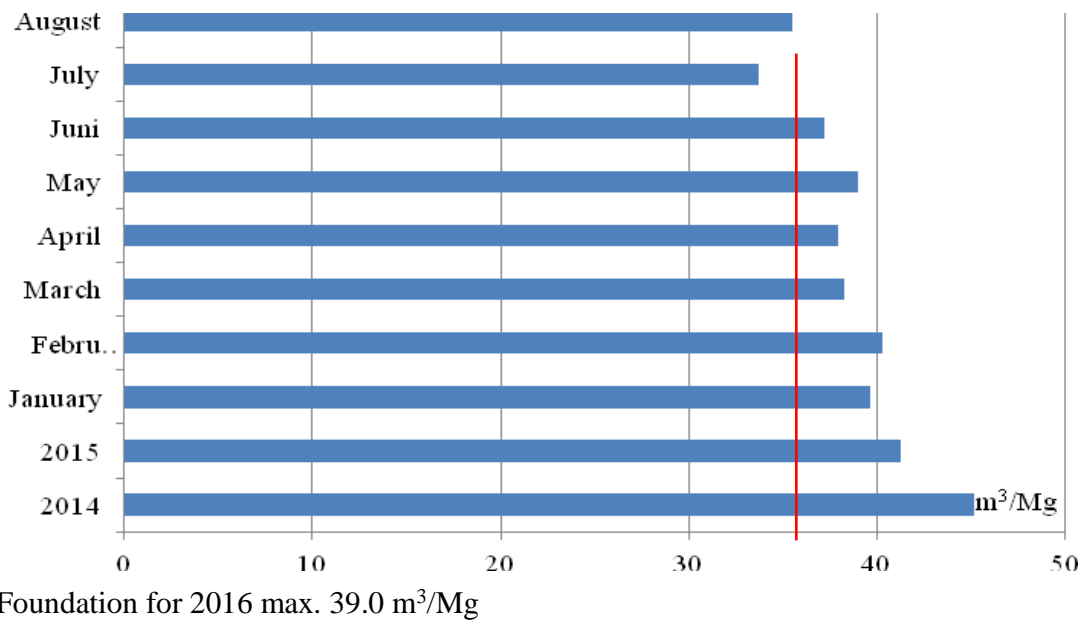

Figure 3. Indicators of gas usage in 2014-2016

Source: Developed based on the company materials

Impact on the consumption of water (Figure 4) has a cooling of the cupola, additions of water to the molding, humidification of the mass returned after treatment of castings at the stage of rotating drum and other consumption resulting from social aspects. The company in aims for 2016 identified the upper limit of water consumption to $1.2 \mathrm{~m}^{3} / \mathrm{Mg}$ while after eight months of activity reached the consumption of $1.02 \mathrm{~m}^{3} / \mathrm{Mg}$. 


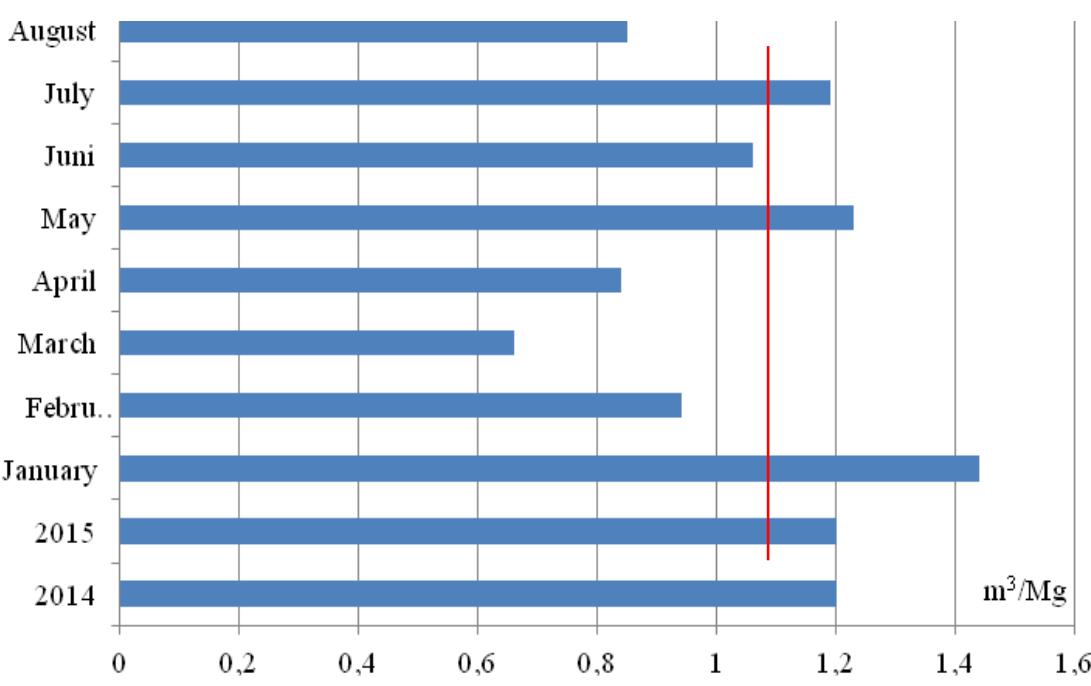

Foundation for $2016 \max .1 .20 \mathrm{~m}^{3} / \mathrm{Mg}$

Figure 4. Indicators of water usage in 2014-2016

Source: Developed based on the company materials

$\mathrm{FeSi}$ is an additive in various metallurgical processes. It is primarily deoxidizer and alloying ingredient. FeSi with high purity is used in production of steel with high magnetic permeability. It is also used in steel making, acting as a regulator in the process of refining. Along with added calcium is used as a modifier and complement of the required chemical composition in different kinds of iron. In the case of the researched company $1 \%$ of the consumption of FeSi (Figure 5) was established as the maximum permissible level. The company for 8 months of 2016 year reached the level of $0.95 \%$, which is well below the specified limit, and contributes to the reduction of production costs.

Figure 6 shows the indicators on the consumption of pellets used in the cleaning process of castings. At this company it is used in mechanical treatmet machine which cleans castings after molding. There are two types of these machines through cleaners (AWP 500) and conveyor cleaners (OWT400). Assumptions for 2016 determined the consumption of pellets used in the production of $3.6 \mathrm{~kg} / \mathrm{Mg}$, real consumption was $3.43 \mathrm{~kg} / \mathrm{Mg}$ on average for eight months. 


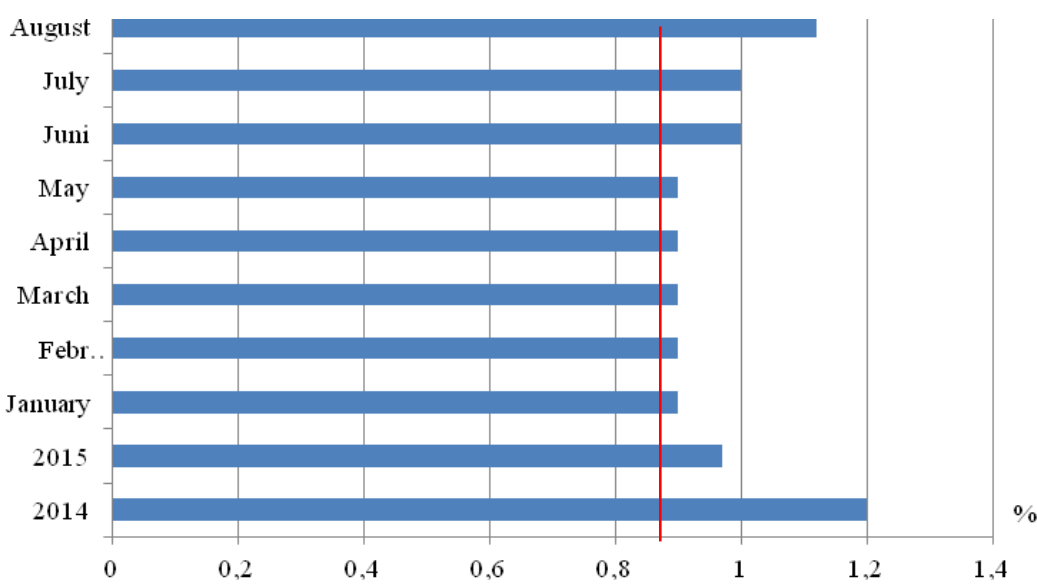

Foundation for 2016 max. 1.0\%

Figure 5. Indicators of FeSi used for production in 2014-2016

Source: Developed based on the company materials

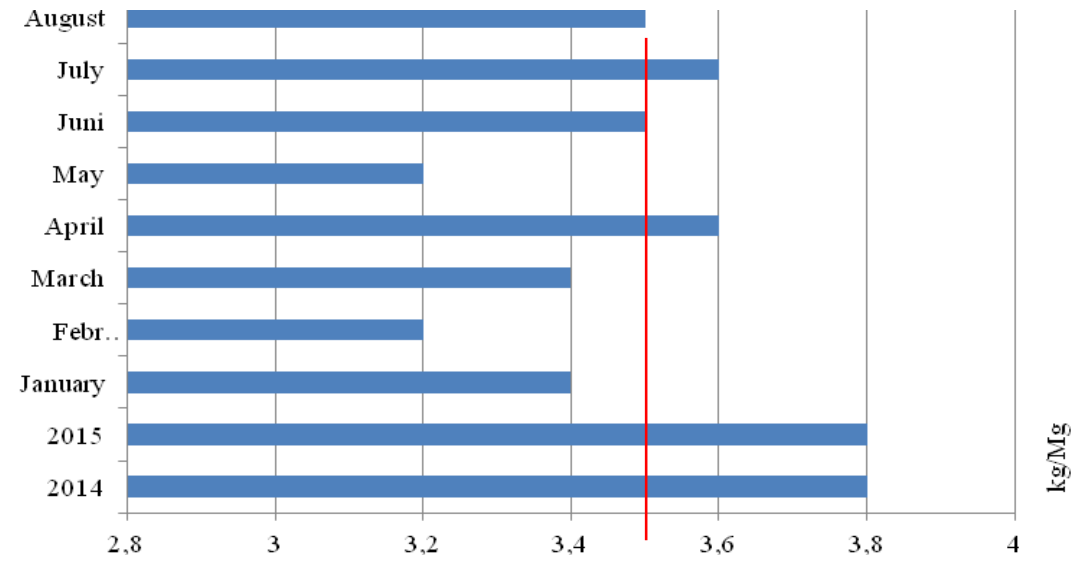

Foundation for $2016 \max .3 .60 \mathrm{~kg} / \mathrm{Mg}$

Figure 6. Indicators of pellet used in production in 2014-2016

Source: Developed based on the company materials

Another indicator is the amount of waste per 1 tonne of castings (Figure 7). Waste can be divided into those originating from molding sand, dust from dedusting devices and other unclassified. Assumptions set for the year 2016 show the maximum amount of waste at the level of $0.750 \mathrm{t}$ per tonne of castings produced. The company had an average value after 8 months of production in the range of $0.728 \mathrm{t}$ per tonne of castings. 


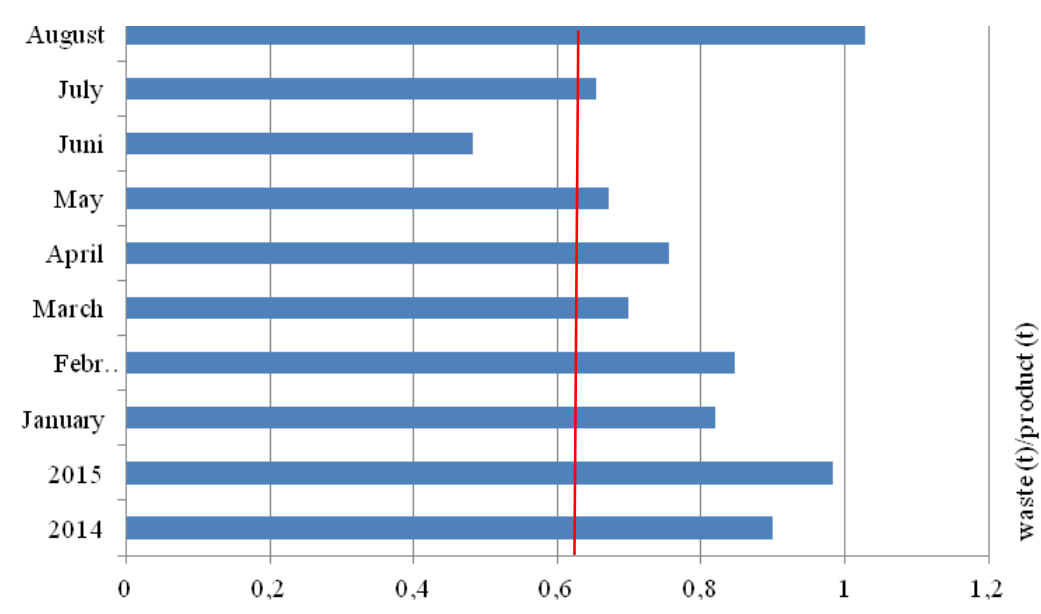

-Foundation for 2016 max. 0.750 waste $(\mathrm{t}) /$ products $(\mathrm{t})$

Figure 7. Indicators of waste produced during production in 2014-2016

Source: Developed based on the company materials

Contemporary globalization processes lead to changes in the structure of economies. They are also responsible for the creation of new specializations and accelerating the disappearance of inefficient sectors. The key concept in determining the possibility of the development of sectors becomes their international competitiveness. The concept that determines the ability to offer goods and services desired by the global market and generating adequate profitability.

In order to analyze the competitiveness of the company should be taken into account a several factors needed to determine all aspects having an influence on it. It should be determined at which level a company shows its competitiveness, does the company manufacture special purpose products?, or compete through their resources?, or competing in a specific market for which we can determine at what level, and whether it is domestic or international. The impact on competitiveness of companies have also factors, both dependent and independent to it. As an example of dependent factors of competitiveness, can be considered as situations in which a company as a business entity by raising their competitiveness increases their chances as an organization for acquisitions of other entities. In contrast, as independent factors there can be considered all the events not related to a business and affecting it, for instance the crisis in the financial market. So to determine the competitiveness of the company, it must simultaneously analyze all the factors relating to: competitive potential, competitive position, competition venues and all the factors that have an influence on it (related to the competitiveness of the company and the unrelated).

The researched company through the production of cast iron with a wide range of applications ranging from construction and ending with a very sophisticated castings for the automotive industry builds its position on the market for many 
years. Implemented investments are an example of the continuous development and awareness of the board as to the validity the implementation of innovations. The platform of competitiveness of this company is in fact the international arena as the company distributes its products in more than $80 \%$ to its clients which place of business are located abroad. The resources in the form of increasingly newer machine park and qualified managers give positive effect in terms of performance of production values. The company, despite the influence of independent factors such as the financial market crisis in 2007, still maintains production levels and the fallen during the crisis, clients replace with new and more demanding. These requirements translate directly into the experience of which the company is richer. At the same time through new experiences increases the range of products which the company can be proud of.

For the competitiveness of the enterprise always a great influence on the effect achieved is the production level compared to the amount of defective products found in the course of production. Defective products resulting from various reasons, raise production costs which directly affects the profitability of the project. Figure 8 shows the results achieved in plant in years from 1997 to 2015.

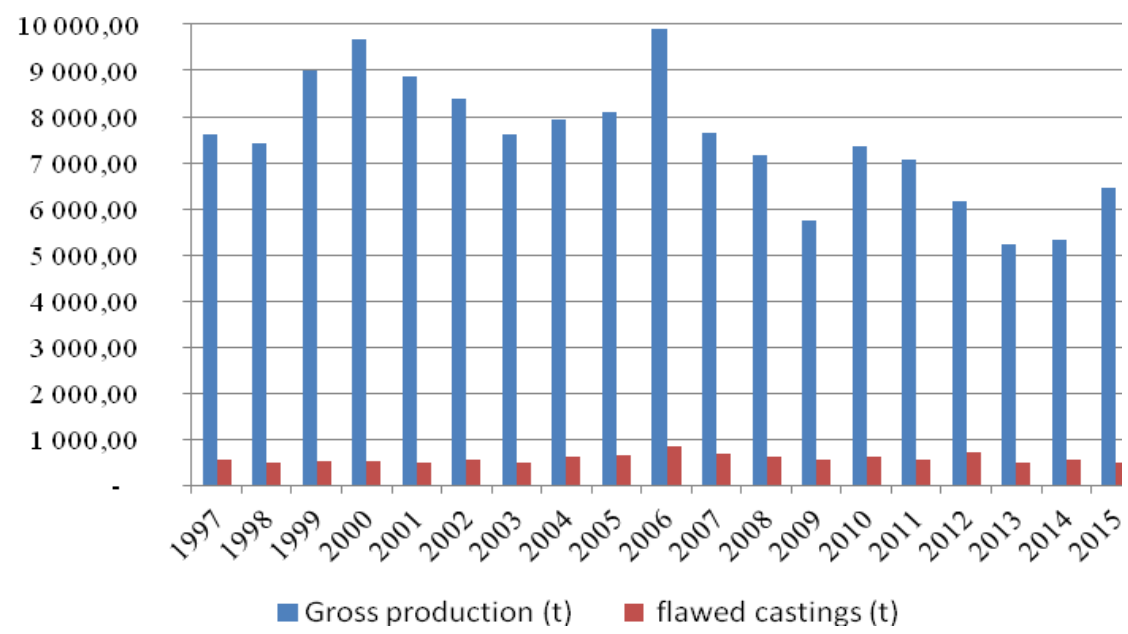

Figure 8. Indicators of quantity of produced castings and flawed castings recognized During Production (1997-2015)

Source: Developed based on the company materials

In the chart we can clearly see a decrease of production after 2007 (the impact of the financial crisis and the related decrease in the number of orders) and the subsequent successful efforts to replace clients who did not survive the crisis on the market. Unfortunately, the implementation of new projects and products are associated with an increase in the amount of defects for a period of implementation which is later included in statements of the annual amount of defected products in comparison to the total produced parts. Figure 9 shows the amount of castings found to be defected by the clients in relation to the amount of castings sold in 
2016. Factor of complaint is also a very important aspect in the pursuit of improving the competitive position of the company as the decreasing number of complaints and its overall score in relation to sales is an indicator of the level of customer satisfaction. The value set as the maximum allowable for 2016 was set at $1.15 \%$ and the company showed the result of 8 months of 2016 year at $0.71 \%$.

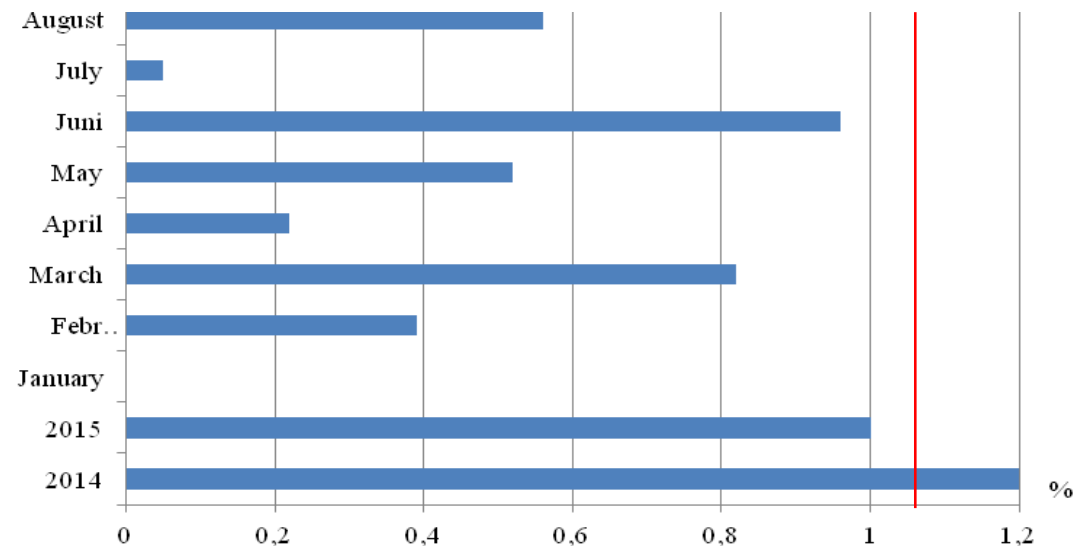

-Foundation for $2016 \max .1 .15 \%$

Figure 9. Indicator of customers complaints in 2014-2016

Source: Developed based on the company materials

\section{Conclusions}

Quality management systems in spite of its complexity and multi-threading, and despite the possibility of many interpretations are an important element in managing the organization. They help to determine the appropriate structure of the organization and determine the appropriate path for its development. Implementation of set through the system objectives helps in understanding the company's strategy and presentation of the various stages of its mission. Management systems through its tools provide the ability to constantly monitor processes in the company and therefore to respond to any issues of concern. Obtaining designated targets on an annual basis and tasks aimed at striving to implement them on a monthly, daily or shift basis depending on how they are determined by a company gives satisfaction but also allows you to understand the dependence of production processes and their impact on the final result of the organization whether it is in form of the market position or generating profits. Skillfully shaped aspects of quality management systems may become a strong side of organization. It can contribute to development of the company but also to create the basis for securing a competitive advantage in the industry. Businesses today cannot afford to disregard the impact of quality management systems on the organizations, as the pursuit of excellence is permanently inscribed in the characteristics of activities in the global market. 


\section{Literature}

1. Berdowski J.B. (2016), Wymagania normy ISO 9001:2015 dotyczace wpływu najwyższego kierownictwa na doskonalenie organizacji w obliczu wyzwań współczesnej gospodarki, "Zarządzanie Jakością", nr 1, p. 22-30.

2. Bieńkowska A., Zabłocka-Kluczka A. (2005), O funkcjach zarządzania jakością. Wędrówka przez chaos - czyli rzecz o zarządzaniu jakościa, "Zarządzanie Jakością", nr 2, p. 77-83.

3. Ejdys J., Kobylińska U., Lulewicz-Sas A. (2012), Zintegrowane systemy zarzadzania jakościa, środowiskiem i bezpieczeństwem pracy, Oficyna Wydawnicza Politechniki Białostockiej, Białystok.

4. Kleniewski A. (2004), Integracja systemów zarzązania jakościa, środowiskiem, bezpieczeństwem i higiena pracy, "Problemy Jakości", nr 11, p. 9-14.

5. Klimecka-Tatar D., Kowalik K. (2017), TQM i Lean Management jako koncepcje zarzadzania rozwojem przedsiębiorstwa nastawionego na doskonalenie jakości, [in:] Wielgórka D. (red.), Wybrane problemy zarządzania nowoczesna organizacja we współczesnej gospodarce, Wydawnictwo Wydziału Zarządzania Politechniki Częstochowskiej, Częstochowa, p. 48-57.

6. Łuczak B. (2011), Geneza zmian w normie ISO 9001:2008, "Problemy Jakości”, nr 5, p. 19-25.

7. Matuszak-Flejszman A. (2010), Integracja systemów zarządzania, [in:] Łańcucki J. (red.), Znormalizowane systemy zarzadzania, Wydawnictwo Uniwersytetu Ekonomicznego, Poznań, p. 199-245.

8. Mroczko F. (2012), Zarzadzanie jakościa, Wałbrzyska Wyższa Szkoła Zarządzania i Przedsiębiorczości, Wałbrzych.

9. Mrozik M. (2013), Zarzązanie jakościa jako przejaw dojrzałości przedsiębiorstw logistycznych, [in:] Skrzypek E. (red.), Dojrzałość organizacji - aspekty jakościowe, Uniwersytet Marii Curie-Skłodowskiej, Lublin, p. 83-90.

10. Olejniczak K. (2015), Innowacje ekologiczne jako narzędzie wspierania zrównoważonego rozwoju, "Zeszyty Naukowe Politechniki Częstochowskiej. Zarządzanie", nr 19, p. 54-62.

11. Olkiewicz M. (2012), Ocena efektów funkcjonowania systemu zarzadzania jakościa w przedsiębiorstwie, "The Journal of Management and Finance", Vol. 3(1), p. 203-215.

12. PN-EN ISO 9000:2006, Systemy zarządzania jakością. Podstawy i terminologia, Polski Komitet Normalizacyjny, Warszawa.

13. Ustawa z dnia 12 września 2002 r. o normalizacji (Dz.U. $2002 \mathrm{nr} 169$ poz. 1386, z późn. zm.).

14. Zawiślak K. (2013), Normalizacja, jakość, konkurencyjność, "Inżynieria Przetwórstwa Spożywczego", nr 1, p. 49-50.

\section{SYSTEM ZARZĄDZANIA JAKOŚCIĄ W FIRMIE - POZYCJA NA RYNKU I PERCEPCJA KLIENTA}

Streszczenie: Jakość produktu/usługi jest kluczowym czynnikiem wpływającym na relacje przedsiębiorstwa z klientami i partnerami biznesowymi. Narzędzia, które mają na celu zagwarantowanie przedsiębiorstwu osiągnięcie i utrzymanie określonego poziomu jakości oferowanych produktów, to systemy zarządzania jakością. Artykuł poświęcono ocenie wpływu systemów zarządzania jakością na konkurencyjność firmy. Cel pracy zrealizowano na podstawie studium przypadku firmy odlewniczej. Kluczowymi efektami wpływu systemu zarządzania jakością na konkurencyjność badanej firmy są minimalizacja zużycia surowców, zasobów naturalnych, liczby braków i reklamacji. Jak wskazuje analiza danych firmy, średnia wartość tych wskaźników utrzymuje się poniżej ustalonych limitów.

Słowa kluczowe: konkurencyjność, zarządzanie, systemy zarządzania jakością 